receiving as much as one hundred guineas for a single operation for ovariotomy. May it not be fair to ask these gentlemen to contribute a trifle to the daughter of one who stood foremost in introducing this operation to the metropolis of London, and so to the whole world?

Tunbridge, Kent.

\section{9 attiruor}

\section{HOSPITAL PRACTICE, BRITISH AND FORETGN.}

Nulla autem est alia pro certo nosrendi via, nisi quamplurimas et morborum et dissectionum historias, tum aliorum, tum proprias collectas habere, et inter se comparare-MonGAGNI De Sed. et Caus. Morb., lib. iv. Procemium.

\section{ST. GEORGE'S HOSPITAL.}

EPILEPSY AND HEMIPLEGIA IN A GOUTY SUBJECT; ARTICULATING GLOSSOPLEGIA FOR SOME DAYS ; RECOVERY

(Under the care of Dr. OGiLe.)

THE nature of the lesion causing the paralysis which is sometimes associated with an attack of gout is not yet fully known. It is, however, only reasonable to suppose that it varies in different cases-being sometimes an embolus, sometimes a thrombus, and sometimes a hæmorrhage; and in a few instances the hypothetical metastasis may probably have an actual existence. The groupings of the external signs can only be explained by the aid of the light which comparatively recent researches have thrown on the hitherto almost unknown regions of cerebral physiology and pathologg.

The patient, William W-, aged sixty-seven, a stableman, was admitted into hospital June 13th. He had been subject to gout, and drank beer, but had not been a hard drinker. About three years previously he had had a "fit," and a second one before Christmas in 1871 ; both attacks occurred in the night, and after the fits he was for some time unable to do any work.

On admission, though he could be partially roused, he was unconscious, having been found in his stable in an insensible condition. He was breathing heavily, with the jaws firmly closed. The face was quite motionless. The right eye was drawn outwards, and the right pupil was smaller than the left one. The right arm and leg were evidently paralysed as regards motion, and the thumb of one hand was swollen, owing to an attack of gout which he had had a week previously. The heart-sounds were distant and muffled, but no valvular or other bruit existed. The subchloride of mercury, followed by castor oil with a drop of croton oil, was administered, and produced free action of the bowels; and strong beef-tea was given. Soon afterwards he regained consciousness.

At the following day's visit the patient was sensible. $\mathrm{H}_{\theta}$ was then quite able to protrude the tongue when bidden. He could not, however, remember his own name, though he clearly understood what was said to him; and he fully knew when the bladder required relief. He had much regained the power of the right arm. There was some want of power in the muscles of the right side of the face, as evinced by imperfect ability to close the right eye as compared with the left; but there was no want of general equilibrium in either side of the face. There was some degres of want of sensibility of the skin of the right arm and leg. There was no difference in the temperature of the two sides of the body. The urine contained a large amount of albumen, and was very acid and very abundant. No urinary casts were found in it. On this day he became unable to pro trude his tongue, though he constantly made efforts, and was able to open his mouth freely. The sensibility of the tongue was unimpaired. This inability to put out the tongue continued for five days. On the sixth day the tongue could be protruded as usual; and about this time the fingers of the left band became affected by gout. This gradually subsided under the use of aperients and the citrate of pot- ash, with wine of colchicum, every four hours. The patien soon left the hospital able to work, a little albumen in the urine only still remaining.

Dr. Ogle nbserved that the case was of a kind which in olden days would probably have been looked upon as an instance of metastasis of gont to the brain. The sudden access and the removal of paralytic symptoms on the approach of gout would, in the eyes of Dr. Pavy for example, have obtained for the case the designation of gouty paralysis.

Dr. Ogle spoke of other cases in which the iuability to protrude the tongue remained after other paraly tic symptoms had passed away. He pointed to some instances of this having occurred after accidents, dwelling specially on an interesting illustration given by a case recorded by Dr. W. Sinkler in Brown-Séquard and Sequin's "Archives of Scientific and Practical Medicine," * of fracture of the lower dorsal vertebræ, with bruisings of the head, in which convulsions and loss of speech and hearing occurred, and in which the patient became quite unable to protrude his tongue. He quite recovered, excepting headache by which he was affected, but remained still unable to put out the tongue.

CONSTANT VOMITING AND HAMATEMESIS REMOVED BY THE RELIEF OF CONSTIPATION BY APERIENTS IN AN HYSTERICAL GIRL.

(Under the care of Dr. OgLe.)

The patient was a young girl, Eliza B-, somewhat hysterical, who had originally been admitted into the surgical wards, but was transferred to Dr. Ogle, who found great pain over the whole of the abdomen and much constipation to accompany the vomiting and bæmorrhage; but the state of the pulse, condition of breathing and of the skin, and also the temperature, were adverse to any supposition of the existence of inflammation. Under the use of purgatives-calomel and jalapine-and small doses of sulphate of magnesia, with enemata and suitable mild diet, all symptoms by degrees disappeared, the pain being greatly relieved by hot spongio-piline saturated with laudanum applied to the abdomen, and the vomiting by hydrocyanicaeid draughts. The amount of alvine evacuation which was expelled under the use of the aperients was immense, and this abundant relief went on from time to time for two or three weeks, even when she was taking but little solid food, indicating the degree to which fæcal accumulation had been going on. Under the subsequent use of valerian, with steel and quinine, and the use of the cold shower-bath, the patient perfectly recovered.

\section{UNIVERSITY COLLEGE HOSPITAL.}

\section{CASES OF HERNIA.}

(Under the care of Mr. Berkelex Hill.)

The following is the conclusion of Mr. Hill's series of hernia cases commenced at page 128 , and continued at page 196.

The subjoined case illustrates the benefit which frequently follows the use of the pneumatic aspirator in cases of strangulated hernia. It may be remarked that, as a rule, when this proceeding fails to do good, it does not produce any injury, and in no way interferes with any subsequent operation. It may, therefore, be attempted as one of the preliminary tentative measures. In some instances, however, its effects have not been merely negative, and in a case in which Mr. Hulke used the aspirator liquid fæces escaped, and continued to flow from the wound after the needle had been withdrawn. This untoward event was accounted for by the fact that as a result of inflammation in the walls of the strangulated intestine the various tunics had become fixed and matted together, so that they did not glide over one another and close the puncture made through them, nor could the mucous membrane "pout" throngh the aperture and close it. It is accordingly desirable, before using the aspirator, to ascertain, if possible, the mechanical and physiological conditions of the obstructed portion of the bowel. It follows, therefore, that although the puncture of 